Volume 5 No 1 September 2019

p-ISSN : $2460-8750$ e-ISSN : $2615-1731$

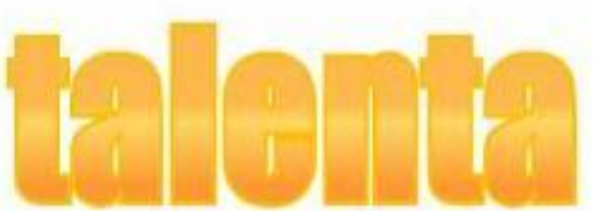

DOI: https://doi.org/10.26858/talenta.v5i1.10633

\title{
HUBUNGAN ANTARA KECERDASAN EMOSI DENGAN STRES KERJA PADA ANGGOTA KEPOLISIAN SATUAN LALU LINTAS POLRESTABES MAKASSAR
}

\author{
Muhammad Ikhsan Baharuddin ${ }^{1}$, Muhammad Jufri², Andi Nasrawati Hamid ${ }^{3}$ \\ Fakultas Psikologi Universitas Negeri Makassar \\ Email: Baharuddinikhsan@gmail.com
}

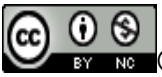

C2019 -JPT Fakultas Psikologi Universitas Negeri Makassar. Ini adalah artikel dengan akses terbuka di bawah licenci CC BY-NC-4.0 (https://creativecommons.org/licenses/by-nc/4.0/).

\begin{abstract}
Abstrak. Anggota kepolisian yang bertugas dilapangan rentang terkena stres kerja yang diakibatkan rendahnya kecerdasan emosi yang dimiliki. Penelitian ini bertujuan untuk mengetahui apakah terdapat hubungan antara kecerdasan emosi dengan stres kerja pada anggota kepolisian Satuan Lantas Polrestabes Makassar. Alat ukur yang digunakan dalam penelitian ini adalah skala kecerdasan emosi dan skala stres kerja. Populasi dalam penelitian ini adalah seluruh anggota satuan lantas polrestabes makassar sebanyak 36 orang. Penelitian ini menggunakan teknik sampel jenuh dalam pengambilan sampelnya, dengan kriteria pengambilan sampel yaitu seluruh anggota kepolisian satuan lantas polrestabes makassar. Data dianalisis menggunakan korelasi product moment, dengan bantuan SPSS 21.0 for windows. Berdasarkan hasil analisa data diperoleh bahwa besarnya kekuatan hubungan antara kecerdasan emosi dengan stres kerja yaitu $r=-0,877$ dan nilai signifikansi 0,000 menunjukkan bahwa probabilitas dibawah 0,01, yang berarti $H_{1}$ diterima. Hal tersebut menunjukkan bahwa ada hubungan yang sangat signifikan antara kecerdasan emosi dengan stres kerja. Semakin tinggi kecerdasan emosi maka semakin rendah stres kerja. Begitupun sebaliknya, semakin rendah kecerdasan emosi maka semakin tinggi stres kerja. Penelitian ini menunjukkan bahwa stres kerja pada anggota kepolisian masih sering terjadi, sehingga dibutuhkan tindakan pemberian pelatihan tentang pengelolaan stres dalam bekerja, preventif, dan edukatif bagi instansi kepolisian sehingga membantu meningkatkan kualitas anggota kepolisian.
\end{abstract}

Kata Kunci: Kecerdasan Emosi, Stres Kerja, Polisi.

Abstract. The members of the police stationed on the field range are exposed to work stress caused by the low emotional intelligence they have. This study aims to determine whether there is a relationship between emotional intelligence and work stress on members of the Makassar Police Police Unit. The measuring instrument used in this study is the emotional intelligence scale and work stress scale. The population in this study were 36 members of the Makassar polrestabes unit. This study uses a saturated sample technique in sampling, with sampling criteria, namely all members of the Makassar police polrestabes unit. Data were analyzed using product moment correlation, with the help of SPSS 21.0 for Windows. Based on the results of data analysis it was found that the magnitude of the relationship between emotional intelligence and work stress is $r=-0,877$ and a significance value of 0,000 indicates that the probability is below 0.01 , which means $\mathrm{Hl}$ is accepted. This shows that there is a very significant relationship between emotional intelligence and work stress. The higher the emotional intelligence, the lower the work stress. Vice versa, the lower the emotional intelligence, the higher the work stress. This study shows that work stress on members of the police is still common, so it takes action to provide training on stress management in work, preventive, and educative for police agencies so as to help improve the quality of police members.

Keywords: Emotional Intelligence, Job Stress, Police. 


\section{PENDAHULUAN}

Kepolisian Negara Republik Indonesia (Polri) merupakan bagian dari birokrasi pemerintahan yang berfungsi sebagai penegak hukum (law enforcement) dan pemelihara ketertiban umum (order maintenance). Secara kelembagaan Polri telah resmi terpisah dari TNI sejak tahun 2000. Tasaripa (2013) mengemukakan bahwa Undang-undang RI No.2 tahun 2002 secara tegas menyatakan bahwa Kepolisian Negara Republik Indonesia merupakan alat negara yang berperan dalam memelihara keamanan dan ketertiban masyarakat, menegakkan hukum serta perlindungan, pengayoman, serta pelayanan masyarakat dalam rangka terpeliharanya keamanan dalam negeri.

Aparat kepolisian berperan untuk menegakkan hukum dan sebagai pengayom bagi masyarakat. Haji, Gunarto dan Widayati (2018) mengemukakan bahwa profesi polisi merupakan profesi yang dinilai dekat dengan segala bentuk kekerasan. Peran polisi sebagai penegak hukum membuat polisi berhadapan dengan para pelanggar hukum yang menuntut polisi untuk bersikap tegas. Ahmad (2008) mengemukakan bahwa profesi polisi dapat dikategorikan sebagai pekerjaan yang rawan terhadap stres. $\mathrm{He} \mathrm{Ni}$, Zhao, dan Archbold (2002) mengemukakan bahwa pekerjaan anggota kepolisian merupakan pekerjaan yang penuh tekanan, dimana polisi tersebut mengalami interaksi langsung dengan publik dan elemen masyarakat yang mengancam maupun antisosial.

Spector (2012) mengemukakan bahwa stres kerja sebagai respon fisik, respon psikologis, dan respon perilaku pekerja terhadap kondisi atau situasi kerja. Rachmawati (2008) mengemukakan bahwa stres merupakan situasi yang berpengaruh terhadap keadaan emosi, kondisi fisik dan pikiran individu.

Lazarus dan Folkman (1984) mengemukakan bahwa stress terbagi dari empat sumber, yaitu frustasi, stress akan muncul apabila usaha yang dilakukan individu untuk mencapai suatu tujuan mendapat hambatan atau kegagalan. Konflik, stress akan muncul apabila individu dihadapkan pada keharusan memilih satu diantara dua dorongan atau kebutuhan yang berlawanan atau yang terdapat pada saat yang bersamaan. Tekanan, stress akan muncul apabila individu mendapat atau paksaan untuk mencapai hasil tertentu dengan cara tertentu. Ancaman, antisipasi individu terhadap hal-hal atau situasi yang merugikan atau tidak menyenangkan bagi dirinya juga merupakan suatu yang dapat memunculkan stress. Spector (2012) mengemukakan bahwa terdapat lima faktor yang dapat mengakibatkan stres kerja, yaitu Ambiguitas peran dan konflik peran, beban kerja, tekanan sosial, kontrol, tuntutan.

Sarwono (2014) mengemukakan bahwa ada beberapa faktor yang menjadi penyebab terjadinya stres yang tinggi pada anggota kepolisian, diantaranya karena ditekan oleh atasan dan rekan kerja dalam waktu yang lama. Selain itu, adanya tindakan kekerasan sehingga menyebabkan korban luka atau tewas seperti pada anggota Sabhara ketika aduh fisik dengan pengunjuk rasa. Jadwal yang terlalu padat sehingga tidak ada waktu untuk istirahat, dan harus selalu siap siaga untuk perintah berikutnya yang banyak dijumpai pada anggota Reserse. Hasil penelitian Hunnur dkk (2014) mengemukakan bahwa analisis berupa Occupational Stress Index dalam $85,5 \%$ dari jumlah 475 responden, terungkap bahwa polisi yang mengalami stres kerja terkategori tinggi berada di departemen tersebut. Menurut National Police Suicide Foundation dalam penelitian Hunnur dkk (2014) mengemukakan bahwa ada sekitar 22 jam yang terambil dalam kehidupan pada anggota polisi di Amerika digunakan untuk 
melaksanakan pekerjaan mereka. Aulya (2013) mengemukakan tentang "FaktorFaktor Yang Berhubungan Dengan Stres Kerja pada Polisi Lalu lintas Di Polda Metro Jakarta Pusat Bulan April sampai Agustus" bahwa faktor yang menunjukkan adanya hubungan dengan stres kerja adalah faktor intrinsik dalam pekerjaan (beban kerja), pengembangan karir (promosi), dan karakteristik individu (umur). Hasil penelitian yang dilakukan oleh Akbar (2013) menunjukkan bahwa adanya hubungan negatif antara kecerdasan emosi dan stres kerja. Semakin tinggi kecerdasan emosi maka semakin rendah stres kerja.

Morash, M Haarr R \& Kwak (2006) mengemukakan tentang "Multilevel Influence on Police Stress" jika polisi yang mengalami tinggi tingkat stresnya dalam pekerjaan mereka keseringan bermasalah dengan penyakit fisik ringan dan masalah psikologis, bahwa hal itu semua mempengaruhi hasil pekerjaan mereka. Gul dan Delice (2011) mengemukakan bahwa menjadi seorang polisi dianggap sebagai pekerjaan dengan tingkat stres yang tinggi, hal ini dikarenakan jam kerja yang panjang, struktur kepemimpinan dan kekhawatiran akan keselamatan.

Salah satu tugas anggota kepolisian yang ada di lapangan yaitu pengendali massa. Supriyadi (2016) mengemukakan bahwa pengendali massa merupakan suatu kegiatan dengan memberikan perlindungan, pengayoman, dan pelayanan terhadap sekelompok masyarakat yang sedang menyampaikan pendapat di depan umum guna mencegah masuknya pengaruh dari pihak tertentu. Upaya untuk mengendalikan massa seringkali berujung pada tindak kekerasan. Beberapa kasus kekerasan yang ditampilkan aparat kepolisian saat menghadapi pengunjuk rasa merupakan salah satu sikap yang menunjukkan kurangnya regulasi emosi yang dimiliki oleh anggota kepolisian.

Berdasarkan hasil wawancara yang dilakukan pada tanggal 16 Januari 2019 dengan Irwasda Polda Sulsel Kombes Pol Robert Haryanto menjelaskan bahwa terdapat dua satuan yang memiliki stres kerja yang tinggi yaitu satuan lantas dan satuan reskrim. Dimana beliau menjelaskan tentang fungsi dan tanggung jawab dari setiap satuan yang dianggap dapat menyebabkan terjadinya stres kerja. Hal ini didukung dengan hasil pengambilan data awal yang peneliti lakukan di polrestabes makassar.

Dari hasil pengambilan data awal yang telah peneliti lakukan di Polrestabes Makassar tentang stres kerja pada anggota Polrestabes Makassar dalam satuan lantas sebanyak 15 orang dan satuan reskrim juga sebanyak 15 orang. Terdapat data kuantitas dari pembagian kuesioner satuan lantas yang mengalami stres kerja yaitu 11 dari 15 orang (73\%). Sedangkan data kuantitas satuan dari pembagian kuesioner satuan reskrim yang mengalami stres kerja yaitu 8 dari 15 orang $(53 \%)$. Data kuantitas dari kedua satuan menunjukkan bahwa terdapat beberapa gejala yang menyebabkan orang mengalami stres kerja yaitu gejala fisik, gejala psikologis, dan gejala perilaku. Maka hasil dari data awal tersebut dapat diindikasikan bahwa satuan lantas memiliki stres kerja paling tinggi dari satuan reskrim.

Selanjutnya, berdasarkan hasil wawancara juga di paparkan oleh anggota Sat Lantas Polrestabes Makassar Aiptu Andi Syahrir mengemukakan bahwa stres yang dialami di tempat kerja biasanya karna banyak kasus yang beliau atasi misalnya, kasus tabrakan ataupun kasus pencurian motor. Terkadang juga beliau merasa tekanan dan beban kerjanya meningkat ketika terdapat kesalahpahaman terhadap atasan yang melihat bahwa kinerja yang beliau lakukan setiap hari itu salah ataupun tidak sesuai dengan aturan dari satuan tersebut. Oleh karena itu, beliau menyimpulkan bahwa dalam satuan Lantas itu biasa banyak mengira bahwa pendapatan tambahan polisi itu ada 
dibagian tersebut tetapi tidak seperti itu, justru satuan ini adalah satuan yang sering disoroti oleh masyarakat tentang perilaku yang tidak baik oleh polisi.

Berdasarkan hasil wawancara diatas diindikasikan bahwa stress yang dialami oleh anggota kepolisian berkaitan dengan tugas pokok pekerjaan, perpindahan jabatan, dan kemampuan individu dalam mengelolah emosi dari lingkungan. Namun, untuk mengatasi stres tersebut, salah satu anggota kepolisian polrestabes makassar Brigpol Muktamar mengatakan bahwa anggota kepolisian yang mengalami stres biasa mengambil keputusan untuk pindah ke satuan yang lain, mengalihkan stressor ke hal lain misalnya cuti ataupun berlibur dengan keluarga, dan mengelolah emosi ke arah yang positif misalnya pergi ke tablig akbar untuk menenangkan pikiran.

Hamid (2016) mengemukakan bahwa Kecerdasan emosi mempengaruhi pilihan perilaku di tempat kerja dan bahkan dapat menentukan seleksi rasional dari tindakan khusus secara efektif dan optimal, bahkan menjadi prioritas yang sangat penting dalam dunia kerja. Goleman (2004) mengemukakan bahwa individu seperti ini juga bisa dikategorikan sebagi individu yang kurang berhasil dalam karirnya. Peristiwa ataupun kejadian luapan emosi yang terjadi pada diri individu, baik ditempat kerja maupun dilingkungan sosial, bisa membawa implikasi kepada tahap kestabilan dan kematangan emosi individu bersangkutan. Melihat fenomena yang terjadi saat ini, mengenai stres kerja pada anggota kepolisian yang kemudian dikaitkan dengan kecerdasan emosi, sehingga peneliti tertarik untuk melakukan riset yang lebih memfokuskan pada hubungan kecerdasan emosi dengan stres kerja pada satuan lantas wilayah polrestabes makassar.

\section{METODE}

Variabel bebas dalam penelitian ini adalah kecerdasan emosi. Kecerdasan emosi merupakan kemampuan anggota kepolisian untuk mengenali perasaan dirinya sendiri dan perasaan dari orang lain, untuk mengukur kecerdasan emosi di gunakan skala kecerdasan emosi yang meliputi aspek kesadaran diri, pengaturan diri, motivasi, empati, dan keterampilan sosial. Dengan adanya kecerdasan emosi anggota kepolisian mampu meminimalisir stres yang terjadi pada dirinya. Variabel terikat adalah stres kerja. Stres kerja merupakan situasi yang menghambat kerja pada anggota polri yang disertai dengan kondisi emosi, proses berpikir, dan kondisi pada saat bekerja, untuk mengukur stres kerja digunakan skala stres kerja yang meliputi aspek psikologis, fisik, dan perilaku.

Populasi dalam penelitian ini adalah satuan lalu lintas polretabes makassar sebanyak 36 orang. Teknik pengambilan sampel yang digunakan yaitu sampel jenuh. Sugiyono (2013) mengemukakan bahwa sampel jenuh merupakan teknik pengambilan sampel dari semua anggota populasi yang dilakukan untuk dijadikan sampel dalam penelitian ini. Berdasarkan ciri-ciri dan sifat tertentu yang mewakili ciri-ciri dan sifat yang telah ditentukan karakteristik subjek yang dapat dijadikan sampel dalam penelitian ini adalah satuan lalu lintas polrestabes Makassar sebanyak 36 orang.

Penyusunan item dalam penelitian ini berdasarkan tiga aspek yaitu psikologis, fisik, dan perilaku yang dikembangkan khusus untuk mengukur stres kerja. Ketiga aspek tersebut dijelaskan oleh Spector (2012) dalam buku Industrial and organizational psychology. Sedangkan terkait dengan data kecerdasan emosi diperoleh dengan menggunakan skala kecerdasan emosi, skala yang digunakan adalah skala model likert. Dan disusun berdasarkan aspek-aspek yang dikemukakan oleh Goleman (2004) yaitu kesadaran diri, pengaturan diri, motivasi, empati, dan keterampilan sosial. Adapun 
uji validasi menggunakan Aiken's $v$ diperoleh pada skala kecerdasan emosi mulai 0,58 sampai dengan 0,83 . Adapun hasil uji validitas Aiken's $v$ bergerak mulai 0,75 sampai dengan 0,92 . Hasil uji daya deskriminasi item pada skala stres kerja diperoleh koefisien korelasi total dari item yang tidak gugur dalam penelitian ini bergerak dari angka 0,252 hingga 0,794. Sedangkan, daya deskriminasi item pada skala kecerdasan emosi koefisien korelasi total dari item yang tidak gugur dalam penelitian ini bergerak dari angka 0,224 hingga 0,703. Hasil Uji Reliabilitas untuk skala stres kerja pada penelitian diperoleh nilai alpha Cronbach sebesar 0,925. Hasil tersebut menunjukkan bahwa tingkat reliabilitas skala stres kerja tergolong bagus. Sedangkan, pada skala kecerdasan emosi diperoleh nilai alpha Cronbach sebesar 0,986 yang menunjukkan bahwa tingkat reliabilitas skala kecerdasan emosi tergolong cukup bagus.

Analisis data yang dilakukan dalam penelitian ini melalui beberapa tahapan, antara lain analisis deskriptif, uji prasyarat yang melalui dua tahap, yaitu uji normalitas dan uji linearitas, kemudian uji hipotesis. Analisis deskriptif adalah analisis data yang bertujuan untuk memberi deskripsi atau gambaran terhadap objek penelitian melalui data sampel atau populasi tanpa membuat kesimpulan yang berlaku untuk umum (Azwar, 2010). Teknik analisis yang digunakan untuk menguji hipotesis dalam penelitian ini yaitu uji korelasi Product moment. Sugiyono (2013) mengemukakan bahwa korelasi product moment bertujuan untuk mengetahui signifikansi hubungan antara variabel dengan melihat kekutan hubungan antara variabel dan melihat arah hubungan.

\section{HASIL DAN PEMBAHASAN}

Subjek penelitian berjumlah 36 orang yang terdiri dari 2 orang polisi wanita dan 34 orang polisi pria. Adapun deskripsi data penelitian untuk data rerata deskripsi dapat dilihat pada tabel sebagai berikut:

\begin{tabular}{ccccc}
\hline \multirow{2}{*}{ Variabel } & \multicolumn{4}{c}{ Deskriptif } \\
\cline { 2 - 5 } & Min & Max & Mean & SD \\
\hline $\begin{array}{c}\text { Kecerdasa } \\
\text { n emosi }\end{array}$ & 35 & 77 & 61 & 10.2 \\
Stres kerja & 47 & 98 & 85 & 11.6 \\
\hline
\end{tabular}

Data hasil penelitian pada skala kecerdasan emosi menunjukkan bahwa untuk skor terendah adalah 35 dan skor tertinggi adalah 77. Adapun kategorisasi Kecerdasan emosi dapat dilihat pada tabel berikut:

\begin{tabular}{cccc}
\hline $\begin{array}{c}\text { Interval } \\
\text { skor }\end{array}$ & F & Presen(\%) & Kategorisasi \\
\hline $\mathrm{x}<49$ & 5 & $13,9 \%$ & Rendah \\
$50 \leq \mathrm{x}<71$ & 8 & $22,2 \%$ & Sedang \\
$72 \leq \mathrm{x}$ & 23 & $63,9 \%$ & Tinggi \\
\hline Total & 36 & $100 \%$ & \\
\hline
\end{tabular}

Data hasil penelitian menunjukkan bahwa mean 61 dengan standar deviasi 10.2. Data hasil penelitian menunjukkan bahwa untuk skor terendah adalah 47 dan skor tertinggi adalah 98. Adapun kategorisasi stres kerja dapat dilihat pada tabel berikut:

\begin{tabular}{cccc}
\hline $\begin{array}{c}\text { Interval } \\
\text { skor }\end{array}$ & F & Presen(\%) & Kategorisasi \\
\hline $\mathrm{x}<72$ & 4 & $11,1 \%$ & Rendah \\
$73 \leq \mathrm{x}<96$ & 30 & $83,3 \%$ & Sedang \\
$97 \leq \mathrm{x}$ & 2 & $5,6 \%$ & Tinggi \\
\hline Total & 36 & $100 \%$ & \\
\hline
\end{tabular}

Hasil uji prasyarat yang digunakan dalam penelitian menggunakan dua metode yaitu uji normalitas dan uji linearitas. Teknik pengujian data yang digunakan pada uji normalitas dalam penelitian ini adalah uji Kolmogrov Smirnov dengan bantuan program SPSS 21.0 for windows. Adapun hasil pengujian dapat dilihat pada tabel berikut:

\begin{tabular}{lll}
\hline Variabel & K-S-Z & Keterangan \\
\hline Kecerdasan emosi & 1,139 & Normal \\
Stres kerja & 1,318 & Normal \\
\hline
\end{tabular}


Berdasarkan tabel diatas, data tersebut menunjukkan bahwa hasil uji normalitas untuk variabel Kecerdasan emosi menunjukkan harga K-S-Z sebesar 1,139 dengan nilai signifikansi 0,149 ( $p>0,05)$, sedangkan untuk variabel stres kerja menunjukkan harga $\mathrm{K}-\mathrm{S}-\mathrm{Z}$ sebesar 1,318 dengan nilai signifikansi $0,062(p>0,05)$. Hasil uji normalitas tersebut menunjukkan bahwa data untuk variabel kecerdasan emosi dn stres kerja berdistribusi normal. Adapun hasil uji linearitas dapat dilihat pada tabel di bawah ini:

\begin{tabular}{cccl} 
Korelasi & F & $\begin{array}{c}\text { Deviation } \\
\text { From } \\
\text { linearity } \\
\text { Sig. }\end{array}$ & Ket \\
\hline Stres & & & \\
kerja*Kec & 5,209 & $0,001<$ & Linier \\
erdasan & $>0,05$ & 0,05 & \\
Emosi & & & \\
\hline
\end{tabular}

Hasil uji linearitas menunjukkan bahwa korelasi stres kerja dengan kecerdasan emosi adalah linier. Tabel diatas menunjukkan bahwa pada Deviation From linearity adalah 0,001 , dimana kaidah yang digunakan untuk Deviation From linearity Sig adalah p $<0,05$ dan pada $\mathrm{F}$ adalah 5,209 , dimana kaidah yang digunakan untuk $\mathrm{F}$ adalah $\mathrm{p}>0,05$. Berdasarkan hasil tersebut dapat disimpulkan bahwa hubungan antara kecerdasan emosi dengan stres kerja adalah linier.

Hipotesis dalam penelitian ini adalah terdapat hubungan antara kecerdasan emosi dengan stres kerja pada anggota kepolisian satu lalu lintas polrestabes Makassar. Hipotesis dalam penelitian ini diuji menggunakan teknik analisis product moment dengan bantuan program SPSS 21.0 for Windows. Hasil dari uji hipotesis dapat dilihat pada tabel di bawah ini:

\begin{tabular}{cccc}
\hline Variabel & $\mathbf{r}$ & $\mathbf{p}$ & Ket \\
\hline $\begin{array}{c}\text { Stres } \\
\text { kerja*kecer } \\
\text { dasan emosi }\end{array}$ & $-0,877$ & $\begin{array}{c}0,000(\mathrm{p} \\
<0,01)\end{array}$ & Signifikan \\
\hline
\end{tabular}

Hasil uji korelasi tersebut menunjukkan hubungan yang signifikan antara kedua variabel. Nilai koefisien korelasi sebesar 0,877 menunjukkan bahwa ada hubungan negatif antara variabel kecerdasan emosi dengan stres kerja.

Berdasarkan Hasil analisis data deskriptif pada skala kecerdasan emosi menujukkan bahwa kecerdasan emosi tergolong sedang. Hasil dari kategorisasi menunjukkan bahwa subjek yang memiliki kecerdasan emosi yang rendah sebanyak 5 $(13,9 \%)$, kecerdasan emosi dalam kategori sedang $8(22,2 \%)$, dan kecerdasan emosi dalam kategori tinggi $23(63,9 \%)$.

Kategorisasi tersebut menunjukkan bahwa kecerdasan emosi pada anggota kepolisian tergolong sedang. Hal tersebut berarti anggota kepolisian mempunyai kecerdasan emosi yang sedang.

Goleman (2004) mengemukakan bahwa kecerdasan antar pribadi merupakan kemampuan untuk dapat memahami orang lain, dan dapat memotivasi individu, kemampuan kinerja, bekerja sama dalam bekerja. Tenaga penjualan yang sukses, politisi, guru, dokter, dan perawat cenderung memiliki kecerdasan emosi yang baik. Hidayati, purwanto, dan yuwono (2008) mengemukakan bahwa kecerdasan emosi yang dialami seorang anggota kepolisian harus memiliki kemampuan yang dapat memberikan motivasi kepada individu ataupun masyarakat disekitarnya. Bahkan, anggota kepolisian mempunyai jiwa kepribadian yang dianggap baik untuk melayani masyarakat.

Berdasarkan hasil analisis data deskriptif pada skala stres kerja menunjukkan bahwa stres kerja tergolong sedang. Hasil dari kategorisasi menunjukkan bahwa subjek yang memiliki stres kerja yang rendah sebanyak 4 $(11,1 \%)$, stres kerja dalam kategori sedang sebanyak 30 (83,3\%), dan stres kerja dalam kategori yang tinggi sebanyak 2 $(5,6 \%)$. 
Kategorisasi tersebut menunjukkan bahwa stres kerja pada anggota kepolisian tergolong sedang, yang berarti anggota kepolisian mampu meminimalisir stres yang mungkin saja terjadi. Hal tersebut berarti bahwa anggota kepolisian yang memiliki tingkat kecerdasan emosi yang tinggi cenderung tidak mengalami stres kerja yang tinggi.

Hal tersebut sesuai dengan pernyataan Bayuwega, Wahyuni dan Kurniawan (2016) mengemukakan bahwa pekerjaan yang memiliki tingkat resiko dan pekerjaan paling tinggi yang berhadapan langsung dengan pelaku adalah anggota kepolisian. Terdapat beberapa kemampuan anggota kepolisian dalam copyng strategy yaitu meningkatnya kesadaran terhadap masalah, pengelolaan informasi, perubahan perilaku, dan resolusi damai.

Berdasarkan Hasil analisis data menunjukkan bahwa hipotesis yang menyebutkan adanya hubungan antara kecerdasan emosi dengan stres kerja pada anggota kepolisian satuan lantas Polrestabes Makassar terbukti diterima. Hal tersebut menunjukkan adanya korelasi antara kecerdasan emosi dengan stres kerja pada anggota kepolisian satuan lantas Polrestabes Makassar. Anggota Kepolisian yang memiliki tingkat kecerdasan emosi yang tinggi akan cenderung memiliki stres kerja yang rendah.

Kekuatan hubungan antara variabel kecerdasan emosi dengan stres kerja dinyatakan dengan nilai $\mathrm{r}$ sebesar $-0,877$. Hal tersebut menunjukkan bahwa korelasi antara kecerdasan emosi dengan stres kerja cukup kuat. Artinya bahwa semakin tinggi kecerdasan emosi, maka semakin rendah stres kerja, begitupun sebaliknya semakin rendah kecerdasan emosi, maka semakin tinggi stres kerja. Hasil penelitian terdahulu yang dilakukan oleh Akbar (2013) mengenai hubungan antara kecerdasan emosi dengan stres kerja pada perawat dihasilkan bahwa kecerdasan emosi perawat tinggi dan stres kerja perawat sedang, sehingga dari hasil penelitian tersebut hipotesis yang berhubungan negatif dapat diterima.

\section{HASIL}

Subjek penelitian berjumlah 36 orang yang terdiri dari 2 orang polisi wanita dan 34 orang polisi pria. Adapun deskripsi data penelitian untuk data rerata deskripsi dapat dilihat pada tabel sebagai berikut:

\begin{tabular}{ccccc}
\hline \multirow{2}{*}{ Variabel } & Min & Max & $\begin{array}{c}\text { Me } \\
\text { an }\end{array}$ & SD \\
\cline { 2 - 5 } & 35 & 77 & 61 & 10.2 \\
$\begin{array}{c}\text { Kecerdasan } \\
\text { emosi }\end{array}$ & & & & \\
Stres kerja & 47 & 98 & 85 & 11.6 \\
\hline
\end{tabular}

Data hasil penelitian pada skala kecerdasan emosi menunjukkan bahwa untuk skor terendah adalah 35 dan skor tertinggi adalah 77. Adapun kategorisasi Kecerdasan emosi dapat dilihat pada tabel berikut:

\begin{tabular}{cccc}
\hline $\begin{array}{c}\text { Interval } \\
\text { skor }\end{array}$ & F & Presen(\%) & Kategorisasi \\
\hline $\mathrm{x}<49$ & 5 & $13,9 \%$ & Rendah \\
$50 \leq \mathrm{x}<$ & 8 & $22,2 \%$ & Sedang \\
71 & 23 & $63,9 \%$ & Tinggi \\
$72 \leq \mathrm{x}$ & 23 & \\
\hline Total & 36 & $100 \%$ & \\
\hline
\end{tabular}

Data hasil penelitian menunjukkan bahwa mean 61 dengan standar deviasi 10.2. Data hasil penelitian menunjukkan bahwa untuk skor terendah adalah 47 dan skor tertinggi adalah 98. Adapun kategorisasi stres kerja dapat dilihat pada tabel berikut:

\begin{tabular}{llll}
\hline Interval skor & F & Presen(\%) & Kategorisasi \\
\hline $\mathrm{x}<72$ & 4 & $11,1 \%$ & Rendah \\
$73 \leq \mathrm{x}<96$ & 30 & $83,3 \%$ & Sedang \\
$97 \leq \mathrm{x}$ & 2 & $5,6 \%$ & Tinggi \\
\hline Total & 36 & $100 \%$ &
\end{tabular}


Hasil uji prasyarat yang digunakan dalam penelitian menggunakan dua metode yaitu uji normalitas dan uji linearitas. Teknik pengujian data yang digunakan pada uji normalitas dalam penelitian ini adalah uji Kolmogrov Smirnov dengan bantuan program SPSS 21.0 for windows. Adapun hasil pengujian dapat dilihat pada tabel berikut:

\begin{tabular}{ccc}
\hline Variabel & K-S-Z & Keterangan \\
\hline $\begin{array}{c}\text { Kecerdasan } \\
\text { emosi }\end{array}$ & 1,139 & Normal \\
Stres kerja & 1,318 & Normal \\
\hline
\end{tabular}

Berdasarkan tabel diatas, data tersebut menunjukkan bahwa hasil uji normalitas untuk variabel Kecerdasan emosi menunjukkan harga K-S-Z sebesar 1,139 dengan nilai signifikansi 0,149 ( $p>0,05)$, sedangkan untuk variabel stres kerja menunjukkan harga $\mathrm{K}-\mathrm{S}-\mathrm{Z}$ sebesar 1,318 dengan nilai signifikansi $0,062(\mathrm{p}>0,05)$. Hasil uji normalitas tersebut menunjukkan bahwa data untuk variabel kecerdasan emosi dn stres kerja berdistribusi normal. Adapun hasil uji linearitas dapat dilihat pada tabel di bawah ini:

\begin{tabular}{|c|c|c|c|}
\hline Korelasi & $\mathbf{F}$ & $\begin{array}{l}\text { Deviation From } \\
\text { linearity Sig. }\end{array}$ & Ket \\
\hline $\begin{array}{c}\text { Stres } \\
\text { kerja*Kec } \\
\text { erdasan } \\
\text { Emosi }\end{array}$ & $\begin{array}{l}5,209 \\
>0,05\end{array}$ & $0,001<0,05$ & Linier \\
\hline
\end{tabular}

Hasil uji linearitas menunjukkan bahwa korelasi stres kerja dengan kecerdasan emosi adalah linier. Tabel diatas menunjukkan bahwa pada Deviation From linearity adalah 0,001 , dimana kaidah yang digunakan untuk Deviation From linearity Sig adalah $\mathrm{p}<0,05$ dan pada $\mathrm{F}$ adalah 5,209 , dimana kaidah yang digunakan untuk $\mathrm{F}$ adalah $\mathrm{p}>0,05$. Berdasarkan hasil tersebut dapat disimpulkan bahwa hubungan antara kecerdasan emosi dengan stres kerja adalah linier.

Hipotesis dalam penelitian ini adalah terdapat hubungan antara kecerdasan emosi dengan stres kerja pada anggota kepolisian satu lalu lintas polrestabes Makassar. Hipotesis dalam penelitian ini diuji menggunakan teknik analisis product moment dengan bantuan program SPSS 21.0 for Windows. Hasil dari uji hipotesis dapat dilihat pada tabel di bawah ini:

\begin{tabular}{cccc}
\hline Variabel & r & p & Ket \\
\hline $\begin{array}{c}\text { Stres } \\
\text { kerja*kecer } \\
\text { dasan emosi }\end{array}$ & $-0,877$ & $\begin{array}{c}0,000(\mathrm{p} \\
<0,01)\end{array}$ & Signifikan \\
\hline
\end{tabular}

Hasil uji korelasi tersebut menunjukkan hubungan yang signifikan antara kedua variabel. Nilai koefisien korelasi sebesar 0,877 menunjukkan bahwa ada hubungan negatif antara variabel kecerdasan emosi dengan stres kerja.

\section{PEMBAHASAN}

Berdasarkan Hasil analisis data deskriptif pada skala kecerdasan emosi menujukkan bahwa kecerdasan emosi tergolong sedang. Hasil dari kategorisasi menunjukkan bahwa subjek yang memiliki kecerdasan emosi yang rendah sebanyak 5 (13,9\%), kecerdasan emosi dalam kategori sedang 8 $(22,2 \%)$, dan kecerdasan emosi dalam kategori tinggi 23 (63,9\%).

Kategorisasi tersebut menunjukkan bahwa kecerdasan emosi pada anggota kepolisian tergolong sedang. Hal tersebut berarti anggota kepolisian mempunyai kecerdasan emosi yang sedang.

Goleman (2004) mengemukakan bahwa kecerdasan antar pribadi merupakan kemampuan untuk dapat memahami orang lain, dan dapat memotivasi individu, kemampuan kinerja, bekerja sama dalam bekerja. Tenaga penjualan yang sukses, politisi, guru, dokter, dan perawat cenderung memiliki kecerdasan emosi yang baik. Hidayati, purwanto, dan yuwono (2008) mengemukakan bahwa kecerdasan emosi yang dialami seorang anggota kepolisian harus memiliki kemampuan yang dapat memberikan motivasi kepada individu ataupun masyarakat disekitarnya. Bahkan, anggota kepolisian mempunyai jiwa kepribadian yang dianggap baik untuk melayani masyarakat.

Berdasarkan hasil analisis data deskriptif pada skala stres kerja 
menunjukkan bahwa stres kerja tergolong sedang. Hasil dari kategorisasi menunjukkan bahwa subjek yang memiliki stres kerja yang rendah sebanyak 4 $(11,1 \%)$, stres kerja dalam kategori sedang sebanyak 30 (83,3\%), dan stres kerja dalam kategori yang tinggi sebanyak 2 $(5,6 \%)$.

Kategorisasi tersebut menunjukkan bahwa stres kerja pada anggota kepolisian tergolong sedang, yang berarti anggota kepolisian mampu meminimalisir stres yang mungkin saja terjadi. Hal tersebut berarti bahwa anggota kepolisian yang memiliki tingkat kecerdasan emosi yang tinggi cenderung tidak mengalami stres kerja yang tinggi.

Hal tersebut sesuai dengan pernyataan Bayuwega, Wahyuni dan Kurniawan (2016) mengemukakan bahwa pekerjaan yang memiliki tingkat resiko dan pekerjaan paling tinggi yang berhadapan langsung dengan pelaku adalah anggota kepolisian. Terdapat beberapa kemampuan anggota kepolisian dalam copyng strategy yaitu meningkatnya kesadaran terhadap masalah, pengelolaan informasi, perubahan perilaku, dan resolusi damai.

Berdasarkan Hasil analisis data menunjukkan bahwa hipotesis yang menyebutkan adanya hubungan antara kecerdasan emosi dengan stres kerja pada anggota kepolisian satuan lantas Polrestabes Makassar terbukti diterima. Hal tersebut menunjukkan adanya korelasi antara kecerdasan emosi dengan stres kerja pada anggota kepolisian satuan lantas Polrestabes Makassar. Anggota Kepolisian yang memiliki tingkat kecerdasan emosi yang tinggi akan cenderung memiliki stres kerja yang rendah.

Kekuatan hubungan antara variabel kecerdasan emosi dengan stres kerja dinyatakan dengan nilai $\mathrm{r}$ sebesar $-0,877$. Hal tersebut menunjukkan bahwa korelasi antara kecerdasan emosi dengan stres kerja cukup kuat. Artinya bahwa semakin tinggi kecerdasan emosi, maka semakin rendah stres kerja, begitupun sebaliknya semakin rendah kecerdasan emosi, maka semakin tinggi stres kerja. Hasil penelitian terdahulu yang dilakukan oleh Akbar (2013) mengenai hubungan antara kecerdasan emosi dengan stres kerja pada perawat dihasilkan bahwa kecerdasan emosi perawat tinggi dan stres kerja perawat sedang, sehingga dari hasil penelitian tersebut hipotesis yang berhubungan negatif dapat diterima.

\section{SIMPULAN DAN SARAN}

\section{A. Kesimpulan}

Berdasarkan pengujian hipotesis dan pembahasan hasil penelitian, maka kesimpulan dari penelitian ini adalah:

1. Tingkat kecerdasan emosi pada anggota kepolisian tinggi

2. Tingkat stres kerja pada anggota kepolisian sedang

3. Terdapat hubungan negatif antara kecerdasan emosi dengan stres kerja pada anggota kepolisian satuan lalu lintas polrestabes Makassar. Semakin tinggi kecerdasan emosi maka semakin rendah stres kerja, begitupun sebaliknya semakin tinggi stres kerja maka semakin rendah kecerdasan emosi anggota kepolisian.

B. Saran

1. Bagi Anggota Kepolisian, dinsarankan untuk mempertahankan kecerdasan emosi agar dapat menciptakan anggota kepolisian yang harmonis untuk masyarakat dan pandai mengelolah stres dalam kondisi apapun saat dalam tugas.

2. Bagi Instansi Kepolisian, diharapkan mampu bekerja sama untuk membuat program berkelanjutan, misalnya dengan memberikan pelatihan secara berkala untuk mempertahankan kecerdasan emosi bagi anggota kepolisian sehingga dapat mengurangi tingkat stres kerja yang terjadi di kalangan anggota kepolisian, agar anggota kepolisian mendapatkan ilmu berkat pelatihan dan dapat memakmurkan bangsa indonesia. 
3. Bagi peneliti selanjutnya, ketika melakukan penelitian yang berkaitan dengan anggota kepolisian maka kita harus lincah dan perhatikan dalam memberikan skala ataupun angket yang telah disediakan karena kebanyakan anggota kepolisian yang sibuk dalam melaksanakan tugasnya sehingga ketika kita memberikan skala tersebut tidak dibaca dengan baik dan tenang.

\section{DAFTAR RUJUKAN}

Ahmad, A. (2008). Job, family and individual factors as predictors of work-family conflict. Jurnal of Human Resource and Adult Learning, 4(1), 57-65.

Akbar, S.N. (2013). Hubungan antara kecerdasan emosi dengan stres kerja pada perawat. Jurnal Ecopsy, 1(1).

Aulya, D. (2013). Faktor-faktor yang berhubungan dengan stres kerja pada polisi lalu lintas di Polres Metro Jakarta Pusat. (Skripsi diterbitkan). Jakarta: Universitas Islam Negeri Syarif Hidayatullah.

Azwar, S. (2010). Metode penelitian. Yogyakarta: Pustaka Pelajar.

Bayuwega, H. G., Wahyuni, I., \& Kurniawan, B. (2016). Faktor-faktor yang berhubungan dengan stres kerja pada anggota Polisi Satuan Reserse Kriminal Polres Blora. Jurnal Kesehatan Masyarakat, 4(4), 673-681.

Goleman, D. (2004). Kecerdasan emosional. Terjemahan oleh $\mathrm{T}$. Hermaya. Jakarta: PT. Gramedia Pustaka Utama.

Gul, Z., \& Delice, M. (2011). Police job stress and stress reduction/ coping program: The effect on the relationship with spouses. Turkish Journal of Police Studies, 13(3), 1938.

Hamid, A, N. (2016). Makna kompetensi emosi bagi manajer dalam pengambilan keputusan. Jurnal Publikasi Pendidikan, 6 (2), 130-140.
Haji, S., Gunarto., \& Widayati. (2018). Implementasi kewenangan diskresi kepolisian dalam penanganan tindak pidana di Polres Demak Jawa Tengah. Jurnal Hukum Khaira Ummah, 13(1), 53-62.

He., Ni., Zhao, J., \& Archbold, C.A. (2002). Gender and police stress the convergent and divergent impact of work einvironment, work-family conflict, and stress coping mechanisms of famale and male police officers. An International Journal of Police Strategies and Management, 25(4), 687-708.

Hunnur, R., Bagali, M.M., \& Sudarshan, S. (2014). Workplace stress - cause of work place stress in Police Departement: A proposal for stress free workplace. Journal of Business and Management (IOSR.JBM), 16(3), 39-47.

Lazarus, R.S., \& Folkman, S. (1984). Stress appraisal and coping. Newyork: Springer Publishing Company, Inc.

Morash, M., Haarr, R., \& Kwak, D. (2006). Multilevel influences on police stress." Jurnal of Contemporary Justice, 22(1), 26-43.

Rachmawati, I. K. (2008). Manajemen sumber daya manusia. Yogyakarta: ANDI.

Sarwono, S.W. (2014). Teori-teori psikologi sosial. Jakarta: Rajawali Pers.

Spector, P. E. (2012). Industrial and organizational psychology: Research and prachce. Chicester: John Wiley \& Sons Inc.

Sugiyono. (2013). Metode penelitian pendidikan pendekatan kuantitatif, kualitatif, dan R\&D. Bandung: Alfabeta.

Supriyadi, T., \& Sarasati, B. (2016). Psikologi kepolisian. Jakarta Timur: Inti Prima Promosindo. 
Tasaripa, K.(2013). Tugas dan fungsi kepolisian dalam perannya sebagai penegak hukum menurut UndangUndang Nomor 2 Tahun 2002 tentang kepolisian. Jurnal Ilmu Hukum Legal Opinion, 1(2). 